\title{
Inter- and intraspecific zonation in three species of sand-burrowing mysids, Archaeomysis kokuboi, A. grebnitzkii and Iiella ohshimai, in Otsuchi Bay, northeastern Japan
}

\author{
Kazutaka Takahashi, Kouichi Kawaguchi \\ Ocean Research Institute, University of Tokyo, 1-15-1 Minamidai, Nakano, Tokyo 164, Japan
}

\begin{abstract}
Seasonal abundance and distribution patterns of the 3 species of sand-burrowing mysids, Archaeomysis kokuboi Ii, A. grebnitzkii Czerniavsky and Iiella ohshimai (Ii), were studied on a sandy beach at Otsuchi Bay, northeastern Honshu, Japan. Clear interspecific bathymetric zonation was recognized among the 3 species. Their habitats shifted seasonally and according to development in species-specific ways. A. kokuboi was the shallowest dweller and was distributed from the swash zone to the step area, where it showed clear intraspecific zonation, i.e. juveniles were mainly distributed just below the step, the most mature mysids occurred above the step and most of the brooding females were restricted to the area close to the shoreline. A. grebnitzkii was found in more offshore areas than A. kokuboi and for the most part their habitats did not overlap. I. ohshimai was distributed in deeper water than the other 2 species and migrated into shallower sites during May to October. Ontogenetic migration to deeper water was evident in A. grebnitzkii and I. ohshimai. Inter- and intraspecific distribution patterns of sand-burrowing mysids may be explained by differences in their responses to wave action or flow regimes near the bottom and also by the distributional patterns and quality of diet in their habitats and their feeding behaviors.
\end{abstract}

KEY WORDS: Archaeomysis - Iiella - Interspecific zonation · Intraspecific zonation · Northeastern Japan

\section{INTRODUCTION}

Sand-burrowing mysids, mainly belonging to the subfamily Gastrosaccinae, occur on sandy coasts throughout tropical to subarctic waters of the world oceans (Mauchline \& Murano 1977). Certain species have been recognized as inhabitants of the swash zone of sandy beaches and are often overwhelmingly predominant (Fishelson \& Loya 1968, Wooldridge 1983). They swim about actively when a wave covers the sand, but burrow into the sand immediately when the wave retreats (Matsudaira et al. 1952, Fishelson \& Loya 1968, Nath \& Pillai 1973, Wooldridge 1983, Hanamura 1992, Jo \& Hanamura 1993). They are known to play an important role in nutrient regeneration in the surf zone (Cockcroft et al. 1988) and are also considered to be distributors of food to beach inter- stitial fauna (Ito 1985). Furthermore, sandy beach mysids make an important contribution as the major source of food for some birds (Moran \& Fishelson 1971, McLachlan et al. 1980).

The genus Archaeomysis, belonging to the Gastrosaccinae, also consists of sand-burrowers which occur abundantly in Japanese waters (Matsudaira et al. 1952, Nishida et al. 1978, 1982, Hanamura 1992, Jo \& Hanamura 1993). Three species of Archaeomysis have been recorded in Japan, 2 of which are considered intertidal species (Matsudaira et al. 1952, Kamihira 1979, Jo \& Hanamura 1993). Archaeomysis kokuboi Ii, 1964 is recognized as an intertidal dweller and is known to be distributed with certainty between $37^{\circ}$ and $43^{\circ} \mathrm{N}$ along Japanese sandy beaches (Matsudaira et al. 1952, Kamihira 1979, Hanamura 1992, Jo \& Hanamura 1993), while Archaeomysis grebnitzkii 
Czerniavsky, 1882 has been collected from the sublittoral zone of the subtropical waters of Japan (Nishida et al. 1978, 1982, Hanamura 1992). A. grebnitzkii has been recorded between 2 to $50 \mathrm{~m}$ depth (Y. Hanamura pers. comm.) and in the Japan Sea is mainly distributed in water shallower than $4 \mathrm{~m}$ (Hirota et al. 1988, Hirota 1992). Based on these occurrence patterns, habitat segregation between the 2 species of Archaeomysis has been suggested (Hanamura 1992). Their detailed distribution patterns, however, are not known since they are sometimes captured together in the same sandy beach habitat (Ii 1964). This paper examines the microdistribution patterns of $A$. grebnitzkii and $A$. kokuboi in a sandy beach at Otsuchi Bay, throughout their life histories. Seasonal occurrence of the less abundant sand-burrowing mysid, Iiella ohshimai (Ii), 1964 , is also described.

\section{MATERIALS AND METHODS}

The study was done at Koshirahama Beach in Otsuchi Bay, on the Pacific coast of northern Honshu, Japan (Fig. 1). Sampling was carried out monthly with a sledge net $(60 \mathrm{~cm}$ width, $40 \mathrm{~cm}$ height, $200 \mu \mathrm{m}$ mesh size) from March 1992 to January 1993. Ten successive $10 \mathrm{~m}$ tows were made along a $100 \mathrm{~m}$ transect line perpendicular to the shoreline. We set buoys at $10 \mathrm{~m}$ intervals along a $100 \mathrm{~m}$ transect line in order to quantify data. To reduce the effect of sea condition and tide, sampling was carried out on calm days around the lowest level of the spring tide. All samples were taken around the lowest spring tide water level. As the lowest tide level varies seasonally, tide level at sampling changed from $0 \mathrm{~cm}$ (above datum, $86 \mathrm{~cm}$ below mean sea level) on 30 June to $100 \mathrm{~cm}$ on 24 November (MSA

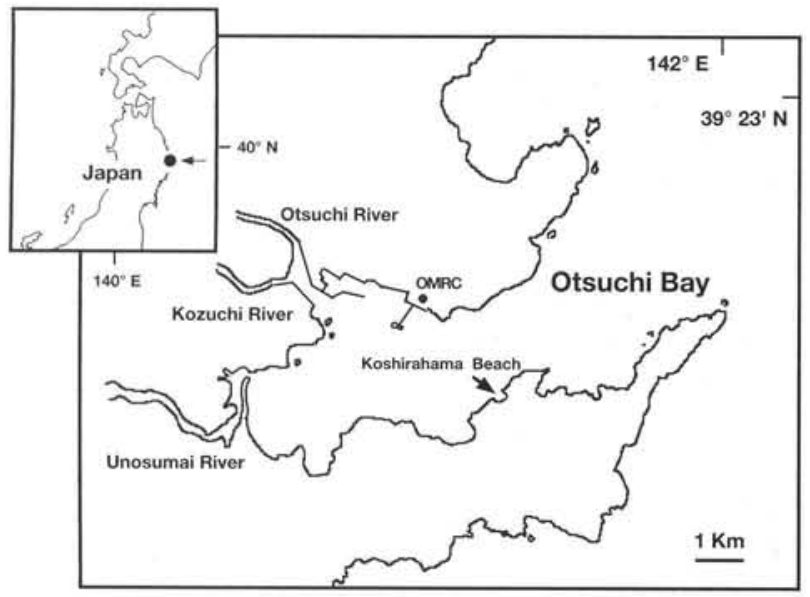

Fig. 1. Location of study site, Koshirahama Beach, Otsuchi Bay, Honshu, Japan. OMRC: Otsuchi Marine Research Center, Ocean Research Institute, University of Tokyo
Table 1. Tidal levels and sampling times. Height of tide is above datum, $86 \mathrm{~cm}$ below mean sea level; Horizontal tide difference is from neap tide line (lower) to shoreline at time of sampling

\begin{tabular}{|c|c|c|c|}
\hline Date & $\begin{array}{l}\text { Height of tide } \\
\text { (cm) }\end{array}$ & $\begin{array}{l}\text { Horizontal tide } \\
\text { difference }(\mathrm{m})\end{array}$ & $\begin{array}{l}\text { Sampling } \\
\text { time }\end{array}$ \\
\hline 3 Mar 1992 & 64 & 3.0 & $09: 32-10: 50$ \\
\hline $4 \mathrm{Apr}$ & 96 & 1.0 & $09: 12-09: 48$ \\
\hline 6 May & 26 & 1.6 & $09: 26-10: 09$ \\
\hline 2 Jun & 10 & 1.1 & $08: 23-09: 20$ \\
\hline 30 Jun & 0 & 0.0 & $08: 54-09: 40$ \\
\hline $31 \mathrm{Jul}$ & 15 & 1.2 & $09: 48-10: 28$ \\
\hline 26 Aug & 22 & 1.7 & $08: 34-09: 15$ \\
\hline 28 Sep & 67 & 3.1 & $09: 45-10: 35$ \\
\hline 26 Oct & 79 & 5.3 & $08: 30-09: 22$ \\
\hline 24 Nov & 100 & 9.1 & $08: 38-09: 22$ \\
\hline $9 \mathrm{Dec}$ & 98 & 9.0 & $08: 09-08: 49$ \\
\hline 22 Jan 1993 & 84 & 5.9 & $08: 43-09: 28$ \\
\hline
\end{tabular}

1992; Table 1). Mean depths at sampling points 20, 50 and $100 \mathrm{~m}$ from the shoreline were 1.6, 3.5 and $5.5 \mathrm{~m}$ respectively.

To investigate the microdistribution of mysids in shallower parts of the fixed sampling transect, sampling by a smaller sledge net $(30 \mathrm{~cm}$ width, $10 \mathrm{~cm}$ height, $330 \mu \mathrm{m}$ mesh size) was done at narrower intervals from the shoreline to $20 \mathrm{~m}$ seaward on 10 June 1993. Five meter tows were made parallel to the shoreline at 14 stations from the swash line to a depth of $2 \mathrm{~m}$.

The samples were fixed in $10 \%$ formalin, identified under a stereo microscope and sorted into groups of different sexual maturity based on Mauchline (1980). When specimens were numerous, samples were subdivided with a Folsom plankton splitter for counting.

\section{STUDY AREA}

Koshirahama Beach is one of the small beaches found in Otsuchi Bay. It is about $120 \mathrm{~m}$ wide and the sand consists of medium-sized granite particles with a few granules of sedimentary rock (Yamanaka et al. 1990). Median particle diameter is about $260 \mu \mathrm{m}$ and beach slope is 1:13.

As sea conditions are calm during summer, definite bar and trough structures were not observed, but a distinct step was recognized. Small troughs were formed during winter to spring when wave action was harsh. The intertidal zone was about $10 \mathrm{~m}$ in width at the study site. The sampling transect line shifted a maximum of $9.1 \mathrm{~m}$ according to seasonal change in tide level (Table 1).

Another sampling series was carried out to investigate the finer microdistribution of mysids on 10 June 1993, when the sea was calm and the tide level was 
$92.6 \mathrm{~cm}$ above datum at sampling. A distinct step developed at a point 8 to $9 \mathrm{~m}$ away from the shoreline, but no bar and trough formation was recognized (see Fig. 2). Sand undulation was continuous from the shoreline to just above the step. Debris from seaweeds and terrestrial materials was swaying around with wave movement just below the step, suggesting an accumulation of floating matter. The grain size of sand changed from Stns 9 to 12, from very coarse on and just below the step to increasingly finer sand seaward from the step. Sand was relatively loose from Stns 9 to 11, but packed tightly with finer grains from Stns 11 to 12 . Sand grains became coarse and ripples continued seaward from Stn 12. According to the scheme of Clifton et al. (1971), the site of microdistributional study is composed of an inner planar facies which occupies the swash zone and commonly extends to the transitional zone between surf and swash (Stns 1 to 7 ), an inner rough facies which extends seaward immediately from the topographic step (Stns 7 to 11), an outer planar facies with a flat and densely packed bottom surface composed of finer sand (Stns 11 to 12) and an outer rough facies which develops seawards of the outer planar facies and has a distinct shoreward-directed lunate mega-ripple (further offshore area beyond Stn 12).

\section{RESULTS}

\section{Distribution patterns of Archaeomysis kokuboi}

Seasonal changes in habitat

More than $99.9 \%$ of Archaeomysis kokuboi occurred within $40 \mathrm{~m}$ of the shoreline throughout the year (Table 2). Within this range, $A$. kokuboi showed a dis- tinct seasonal habitat change. From November to early June, about $98 \%$ of $A$. kokuboi were widely distributed in the $0-30 \mathrm{~m}$ zone with peaks in the $10-20 \mathrm{~m}$ zone, except in January 1993 when the peak was observed in the $0-10 \mathrm{~m}$ zone. Most individuals moved to the shallower area within $10 \mathrm{~m}$ of the shoreline during late June to October with $97.7 \%$ of total individuals collected in this shallowest zone.

Monthly distribution patterns of adults, immature mysids and juveniles are shown in Table 3. Seasonal change, as mentioned above, was observed in all developmental stages, although the distributional range and the peak abundances were different for the 3 stages. Adults occurred closest to the shoreline and their abundance peak was observed in the $0-10 \mathrm{~m}$ zone, except for a few occasions such as April and December when the peak shifted seaward and occurred in the $10-20 \mathrm{~m}$ zone (Table 3). From May to October, 90 to $100 \%$ of the adult population was concentrated within the $0-10 \mathrm{~m}$ zone. Mean percentages of occurrence in the $0-10$ and $10-20 \mathrm{~m}$ zones are 78.7 and $19.0 \%$, respectively, throughout the year, indicating that almost all of the adults occurred within $20 \mathrm{~m}$ of the shoreline.

From late fall to spring, immature mysids tended to occur slightly seaward compared to adults but their distribution was not so different from that of the adults, with more than $99 \%$ of total individuals restricted to the $0-10 \mathrm{~m}$ zone from late June to November (Table 3).

Among the 3 stages, juveniles showed the widest distribution in the $0-40 \mathrm{~m}$ zone from November to early June, but from late June to October more than $96 \%$ were concentrated in the $0-10 \mathrm{~m}$ zone and disappeared from the $20-40 \mathrm{~m}$ zone (Table 3). From November to March, juveniles gradually moved seaward and the percentage of individuals collected beyond $20 \mathrm{~m}$ from the shoreline increased, i.e. $7.5 \%$ in

Table 2. Archaeomysis kokuboi. Monthly abundances ( $\%$ of total catch) in each sampling zone along a $100 \mathrm{~m}$ transect line at Koshirahama Beach. Bold type indicates values $>10 \%$, $+:<0.1 \% ;-$ : no mysids collected; nd: no data

\begin{tabular}{|c|c|c|c|c|c|c|c|c|c|c|c|c|}
\hline \multirow[t]{2}{*}{ Date } & \multirow{2}{*}{$\begin{array}{l}\text { Total } \\
\text { catch }\end{array}$} & \multirow{2}{*}{$\begin{array}{l}\text { Average den- } \\
\text { sity (ind. } \mathrm{m}^{-2} \text { ) }\end{array}$} & \multicolumn{10}{|c|}{ Distance from shoreline $(\mathrm{m})$} \\
\hline & & & $0-10$ & $10-20$ & $20-30$ & $30-40$ & $40-50$ & $50-60$ & $60-70$ & $70-80$ & $80-90$ & $90-100$ \\
\hline 3 Mar 1992 & 1505 & 79.1 & 24.3 & 41.2 & 29.2 & 5.0 & 0.3 & - & + & - & - & + \\
\hline $4 \mathrm{Apr}$ & 2430 & 189.7 & 33.8 & 59.9 & 4.6 & 1.7 & + & - & - & - & - & - \\
\hline 6 May & 1916 & 106.4 & 22.3 & 44.1 & 33.6 & - & - & - & - & - & - & - \\
\hline 2 Jun & 9407 & 783.6 & 33.0 & 67.0 & + & - & - & - & nd & nd & nd & nd \\
\hline 30 Jun & 5334 & 886.3 & 99.7 & 0.3 & - & - & - & - & - & - & - & - \\
\hline $31 \mathrm{Jul}$ & 30913 & 5105.3 & 99.1 & 0.9 & - & - & - & - & - & - & - & - \\
\hline 26 Aug & 679 & 113.0 & 99.9 & 0.1 & - & - & - & - & - & - & - & - \\
\hline 28 Sep & 1300 & 208.8 & 95.0 & 5.0 & - & - & - & - & - & - & - & - \\
\hline 26 Oct & 5057 & 800.3 & 95.0 & 4.9 & 0.1 & + & - & - & - & - & - & - \\
\hline $24 \mathrm{Nov}$ & 8508 & 702.7 & 24.7 & 74.4 & 0.9 & - & - & - & - & - & - & - \\
\hline 9 Dec & 15612 & 2159.8 & 1.1 & 83.0 & 14.7 & 1.1 & 0.1 & - & - & + & - & + \\
\hline 22 Jan 1993 & 3200 & 169.5 & 45.8 & 22.1 & 27.5 & 4.3 & 0.3 & - & + & - & - & - \\
\hline
\end{tabular}


Table 3. Archaeomysis kokuboi. Monthly abundances (\% of total catch) of different maturity stages in each sampling zone along a $100 \mathrm{~m}$ transect line at Koshirahama Beach. Bold type indicates values $>10 \%$. +: <0.1\%; -: no mysids collected; nd: no data

\begin{tabular}{|c|c|c|c|c|c|c|c|c|c|c|c|c|}
\hline \multirow[t]{2}{*}{ Date } & \multirow{2}{*}{$\begin{array}{l}\text { Total } \\
\text { catch }\end{array}$} & \multirow{2}{*}{$\begin{array}{l}\text { Average den- } \\
\text { sity (ind. } \mathrm{m}^{-2} \text { ) }\end{array}$} & \multicolumn{10}{|c|}{ Distance from shoreline (m) } \\
\hline & & & $0-10$ & $10-20$ & $20-30$ & $30-40$ & $40-50$ & $50-60$ & $60-70$ & $70-80$ & $80-90$ & $90-100$ \\
\hline \multicolumn{13}{|l|}{ Adults } \\
\hline 3 Mar 1992 & 312 & 17.1 & 53.5 & 32.4 & 12.5 & 1.6 & - & - & - & - & - & - \\
\hline $4 \mathrm{Apr}$ & 1367 & 107.6 & 31.1 & 63.4 & 3.4 & 2.1 & 0.1 & - & - & - & - & - \\
\hline 6 May & 384 & 55.3 & 92.7 & 7.3 & - & - & - & - & - & - & - & - \\
\hline 2 Jun & 262 & 40.6 & 93.1 & 6.9 & - & - & - & - & nd & nd & nd & nd \\
\hline 30 Jun & 172 & 28.6 & 100.0 & - & - & - & - & - & - & - & - & - \\
\hline 31 Jul & 3649 & 608.0 & 100.0 & - & - & - & - & - & - & - & - & - \\
\hline 26 Aug & 155 & 25.8 & 100.0 & - & - & - & - & - & - & - & - & - \\
\hline $28 \mathrm{Sep}$ & 34 & 5.6 & 100.0 & - & - & - & - & - & - & - & - & - \\
\hline $26 \mathrm{Oct}$ & 203 & 33.8 & 98.0 & 2.0 & - & - & - & - & - & - & - & - \\
\hline 24 Nov & 519 & 43.3 & 67.2 & 32.8 & - & - & - & - & - & - & - & - \\
\hline $9 \mathrm{Dec}$ & 248 & 19.8 & 23.8 & 72.2 & 4.0 & - & - & - & - & - & - & - \\
\hline $22 \operatorname{Jan} 1993$ & 110 & 8.8 & 85.5 & 10.9 & 2.7 & 0.9 & - & - & - & - & - & - \\
\hline \multicolumn{13}{|c|}{ Immature mysids } \\
\hline 3 Mar 1992 & 854 & 129.3 & 3.2 & 90.9 & 5.7 & 0.1 & - & - & - & - & - & 0.1 \\
\hline $4 \mathrm{Apr}$ & 1700 & 135.7 & 61.4 & 34.4 & 3.6 & 0.6 & - & - & - & - & - & - \\
\hline 6 May & 27 & 4.5 & 100.0 & - & - & - & - & - & - & - & - & - \\
\hline 2 Jun & 3074 & 256.2 & 65.6 & 34.4 & - & - & - & - & nd & nd & nd & nd \\
\hline $30 \mathrm{Jun}$ & 842 & 140.3 & 100.0 & - & - & - & - & - & - & - & - & - \\
\hline $31 \mathrm{Jul}$ & 19352 & 3222.7 & 99.9 & 0.1 & - & - & - & - & - & - & - & - \\
\hline 26 Aug & 498 & 82.8 & 99.8 & 0.2 & - & - & - & - & - & - & - & - \\
\hline 28 Sep & 131 & 21.8 & 100.0 & - & - & - & - & - & - & - & - & - \\
\hline $26 \mathrm{Oct}$ & 1826 & 301.2 & 99.0 & 1.0 & - & - & - & - & - & - & - & - \\
\hline 24 Nov & 5024 & 417.7 & 30.2 & 69.6 & 0.2 & - & - & - & - & - & - & - \\
\hline 9 Dec & 7905 & 1107.0 & 1.5 & 88.8 & 9.7 & - & - & - & - & - & - & - \\
\hline 22 Jan 1993 & 2144 & 166.3 & 63.5 & 19.8 & 14.4 & 2.3 & - & - & - & - & - & - \\
\hline \multicolumn{13}{|l|}{ Juveniles } \\
\hline 3 Mar 1992 & 171 & 9.1 & 1.8 & 37.4 & 46.2 & 12.3 & 1.8 & - & 0.6 & - & - & - \\
\hline $4 \mathrm{Apr}$ & 10 & 0.5 & 10.0 & 30.0 & 30.0 & 30.0 & - & - & - & - & - & - \\
\hline 6 May & 1505 & 121.7 & 3.0 & 54.2 & 42.8 & - & - & - & - & - & - & - \\
\hline 2 Jun & 6007 & 500.6 & 14.0 & 86.0 & - & - & - & - & nd & nd & nd & nd \\
\hline 30 Jun & 4320 & 717.3 & 99.6 & 0.4 & - & - & - & - & - & - & - & - \\
\hline $31 \mathrm{Jul}$ & 7912 & 1274.7 & 96.7 & 3.3 & - & - & - & - & - & - & - & - \\
\hline 26 Aug & 26 & 4.3 & 100.0 & - & - & - & - & - & - & - & - & - \\
\hline 28 Sep & 1300 & 205.8 & 95.0 & 5.0 & - & - & - & - & - & - & - & - \\
\hline $26 \mathrm{Oct}$ & 3085 & 466.0 & 90.6 & 7.3 & 2.1 & - & - & - & - & - & - & - \\
\hline $24 \mathrm{Nov}$ & 3141 & 444.0 & 7.6 & 84.8 & 2.0 & 5.5 & - & - & - & - & - & - \\
\hline $9 \mathrm{Dec}$ & 7459 & 606.0 & 0.1 & 77.2 & 20.3 & 2.3 & 0.1 & - & - & + & - & + \\
\hline $22 \operatorname{Jan} 1993$ & 946 & 69.8 & 1.2 & 28.4 & 60.0 & 9.2 & 1.1 & - & 0.1 & - & - & - \\
\hline
\end{tabular}

November, $22.7 \%$ in December, $70.4 \%$ in January and $79.9 \%$ in March. Throughout the summer, juveniles remained in the $0-10 \mathrm{~m}$ zone.

\section{Microdistribution near the shoreline}

The microdistribution close to the shoreline in summer was studied between the shoreline and a point $20 \mathrm{~m}$ offshore as shown in Fig. 2.

About $77 \%$ of juveniles occurred at Stns 9 to 11, just below the step which is formed at a 9 to $12 \mathrm{~m}$ distance from the shoreline. However they were rare above the step and in the offshore zone beyond Stn 12. Mature males and immature idividuals of both sexes showed a wide range of distribution with some quantitative peaks at Stns 5 and 6 just above the step and smaller peaks at Stns 9 to 11 just below the step. Immature females were also relatively abundant at Stn 3 where adult females were dominant. Mature females were divided into 4 categories according to maturation of the embryo in the brood pouch, i.e, females having an empty brood pouch, brood pouch with egg-shaped embryos, eyeless larvae and eyed larvae (Fig. 2). Females having an empty brood pouch and those with egg-shaped embryos were widely distributed from Stns 2 to 8 , in the $1-8 \mathrm{~m}$ range from the shoreline above the step, but with growth of the embryos they tended to 


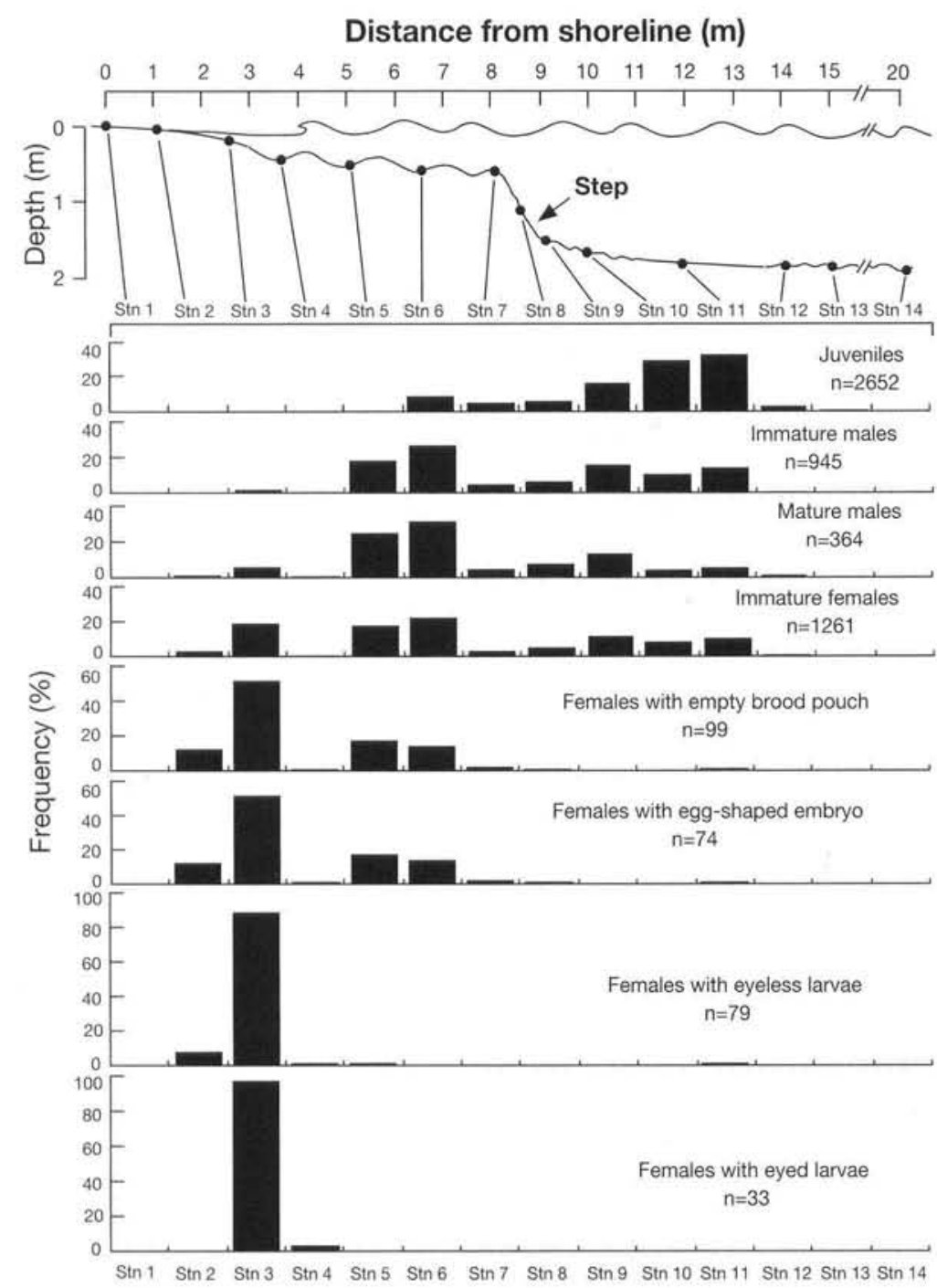

Fig. 2. Archaeomysis kokuboi. Microdistribution in the nearshore area, 10 June 1993 on Koshirahama Beach move into the shallower zone within the 1-3 $\mathrm{m}$ range, i.e. more than $90 \%$ of females with eyeless and eyed larvae were at $\operatorname{Stn} 3$, $3 \mathrm{~m}$ from the shoreline.

\section{Seasonal changes in abundance}

Average densities of Archaeomysis kokuboi per $\mathrm{m}^{2}$ in its habitat, defined as the sampling zone where more than $10 \%$ of the total catch (bold type in Table 2) was collected, varied from 79.1 in March to 5105.3 ind. $\mathrm{m}^{-2}$ in July (Table 2). In spring its habitat is relatively wide, and densities were low, 79.1 to 189.7 ind. $\mathrm{m}^{-2}$. From June, the density started to increase as small individuals began recruitment (Table 3). Their habitat became restricted to a narrow zone along the shoreline and their density increased drastically to 783.6 to 5105.3 ind. $\mathrm{m}^{-2}$ during June-July. In August, the density decreased to 113 ind. $\mathrm{m}^{-2}$, but after that increased gradually to a second peak of 2159.8 ind. $\mathrm{m}^{-2}$ during December. In January, an expansion of the habitat and a decrease of total individuals resulted in falling densities.

\section{Distribution patterns of Archaeomysis grebnitzkii}

Seasonal changes in habitat

Archaeomysis grebnitzkii showed a wider and deeper distribution (Table 4) than A. kokuboi. From January to April,

Table 4. Archaeomysis grebnitzkii. Monthly abundances (\% of total catch) in each sampling zone along a $100 \mathrm{~m}$ transect line at Koshirahama Beach. Bold type indicates values $>10 \%,+:<0.1 \%$; ; no mysids collected; nd: no data

\begin{tabular}{|c|c|c|c|c|c|c|c|c|c|c|c|c|}
\hline \multirow{2}{*}{ Date } & \multirow{2}{*}{$\begin{array}{l}\text { Total } \\
\text { catch }\end{array}$} & \multirow{2}{*}{$\begin{array}{l}\text { Average den- } \\
\text { sity (ind. } \mathrm{m}^{-2} \text { ) }\end{array}$} & \multicolumn{10}{|c|}{ Distance from shoreline (m) } \\
\hline & & & $0-10$ & $10-20$ & $20-30$ & $30-40$ & $40-50$ & $50-60$ & $60-70$ & $70-80$ & $80-90$ & $90-100$ \\
\hline 3 Mar 1992 & 331 & 10.2 & - & - & 0.6 & 4.8 & 14.5 & 31.7 & 22.4 & 11.5 & 12.1 & 2.4 \\
\hline 4 Apr & 214 & 8.0 & 0.5 & - & 4.2 & 3.3 & 20.1 & 25.2 & 19.2 & 23.8 & 3.7 & - \\
\hline 6 May & 131 & 6.0 & 0.7 & 8.4 & 38.2 & 21.4 & 22.9 & 3.8 & 3.8 & 0.8 & - & - \\
\hline 2 Jun & 1921 & 150.9 & 0.9 & 77.6 & 16.6 & 3.9 & 0.9 & 0.1 & nd & nd & nd & nd \\
\hline 30 Jun & 5790 & 293.7 & 18.3 & 62.1 & 10.9 & 6.5 & 1.3 & 0.5 & 0.2 & 0.2 & + & + \\
\hline $31 \mathrm{Jul}$ & 3155 & 248.3 & 24.1 & 70.0 & 3.8 & 0.8 & 0.2 & 0.3 & 0.3 & 0.4 & + & 0.1 \\
\hline 26 Aug & 415 & 18.8 & 16.4 & 37.8 & 28.0 & 9.4 & 3.1 & 0.5 & 2.4 & 0.5 & 1.2 & 0.7 \\
\hline 28 Sep & 338 & 26.4 & 30.8 & 63.0 & 5.6 & 0.3 & 0.3 & - & - & - & - & - \\
\hline $26 \mathrm{Oct}$ & 588 & 13.6 & 0.2 & 15.8 & 15.9 & 12.4 & 13.2 & 13.9 & 12.2 & 9.2 & 4.1 & 3.1 \\
\hline $24 \mathrm{Nov}$ & 7423 & 521.5 & - & 7.0 & 38.1 & 46.2 & 7.3 & 0.8 & 0.3 & 0.1 & 0.1 & 0.1 \\
\hline $9 \mathrm{Dec}$ & 5524 & 272.7 & - & 1.0 & 26.8 & 45.0 & 17.0 & 6.0 & 1.9 & 1.4 & 0.6 & 0.2 \\
\hline 22 Jan 1993 & 259 & 9.3 & - & - & 1.9 & 7.3 & 15.4 & 23.6 & 27.0 & 20.5 & 3.1 & 1.2 \\
\hline
\end{tabular}


more than $90 \%$ of individuals occurred in the offshore area more than $40 \mathrm{~m}$ distant from the shoreline and were rare in the $0-30 \mathrm{~m}$ zone. In May and early June, they gradually moved shoreward. From June through September, about $90 \%$ of the A. grebnitzkii population was distributed within the $0-30 \mathrm{~m}$ zone from the shoreline. From October they started to move seaward and almost all the population returned to their winter-spring habitat.

Monthly distribution patterns of adults, immature mysids and juveniles are shown in Table 5. Adults had the widest distribution range among the 3 stages. Throughout the year, almost all adults occurred in the $10-80 \mathrm{~m}$ zone and were rare in the $0-10 \mathrm{~m}$ zone except for September (Table 5). Seasonal movement, however was recognized within the $10-80 \mathrm{~m}$ zone. From May through August, they were mainly distributed in the $10-50 \mathrm{~m}$ zone. Mean percentages of occurrence in the the 10-20, 20-30, 30-40 and 40-50 m zones during this period were $13.4,24.9,27.9$ and $15.1 \%$ respectively. The shallow distributional range found in September expanded seaward from October to December. From January to April, their distribution tended to be restricted to the $40-80 \mathrm{~m}$ zone, as suggested by the fact that $93.9 \%$ of adult individuals were collected in this zone. Mean percentages of occurrence in the 40-50, 50-60, 60-70 and 70-80 $\mathrm{m}$ zones during January to April were $26.9,31.8,22.8$ and $12.4 \%$ respectively.

Table 5. Archaeomysis grebnitzkii. Monthly abundances (\% of total catch) of different maturity stages in each sampling zone along a $100 \mathrm{~m}$ transect line at Koshirahama Beach. Bold type indicates values $>10 \%$. +: $<0.1 \%$; - : no mysids collected; nd: no data

\begin{tabular}{|c|c|c|c|c|c|c|c|c|c|c|c|c|}
\hline \multirow[t]{2}{*}{ Date } & \multirow{2}{*}{$\begin{array}{l}\text { Total } \\
\text { catch }\end{array}$} & \multirow{2}{*}{$\begin{array}{l}\text { Average den- } \\
\text { sity (ind. } \mathrm{m}^{-2} \text { ) }\end{array}$} & \multicolumn{10}{|c|}{ Distance from shoreline (m) } \\
\hline & & & $0-10$ & $10-20$ & $20-30$ & $30-40$ & $40-50$ & $50-60$ & $60-70$ & $70-80$ & $80-90$ & $90-100$ \\
\hline \multicolumn{13}{|l|}{ Adults } \\
\hline 3 Mar 1992 & 14 & 0.4 & - & - & 14.3 & 7.1 & 21.4 & 14.3 & 28.6 & 14.3 & - & - \\
\hline $4 \mathrm{Apr}$ & 74 & 2.6 & 1.4 & - & 6.8 & 4.1 & 14.9 & 31.1 & 14.9 & 23.0 & 4.1 & - \\
\hline 6 May & 120 & 5.4 & 0.8 & 8.3 & 37.5 & 20.8 & 23.3 & 4.2 & 4.2 & 0.8 & - & - \\
\hline 2 Jun & 34 & 1.3 & - & 23.5 & 23.5 & 29.4 & 17.6 & 5.9 & nd & nd & nd & nd \\
\hline 30 Jun & 303 & 10.5 & 3.0 & 11.9 & 19.5 & 38.0 & 14.2 & 6.9 & 3.0 & 3.3 & 0.3 & - \\
\hline 31 Jul & 67 & 1.6 & - & 10.4 & 20.9 & 20.9 & 7.5 & 11.9 & 13.4 & 10.4 & 1.5 & 3.0 \\
\hline 26 Aug & 108 & 3.6 & 6.5 & 13.0 & 23.1 & 30.6 & 13.0 & 3.7 & 7.4 & 0.9 & 0.9 & 0.9 \\
\hline 28 Sep & 21 & 1.8 & 61.9 & 38.1 & - & - & - & - & - & - & - & - \\
\hline $26 \mathrm{Oct}$ & 128 & 3.0 & - & 7.8 & 12.5 & 7.8 & 16.4 & 17.2 & 10.9 & 13.3 & 8.6 & 5.5 \\
\hline $24 \mathrm{Nov}$ & 42 & 1.1 & - & 16.7 & 11.9 & 21.4 & 2.4 & 11.9 & 16.7 & 4.8 & 7.1 & 7.1 \\
\hline $9 \mathrm{Dec}$ & 20 & 0.8 & - & - & 15.0 & 25.0 & 45.0 & 10.0 & 5.0 & - & - & - \\
\hline 22 Jan 1993 & 4 & 0.2 & - & - & - & - & 25.0 & 50.0 & 25.0 & - & - & - \\
\hline \multicolumn{13}{|c|}{ Immature mysids } \\
\hline 3 Mar 1992 & 294 & 9.1 & - & - & - & 4.1 & 14.3 & 32.3 & 22.8 & 11.2 & 12.6 & 2.7 \\
\hline $4 \mathrm{Apr}$ & 108 & 4.1 & - & - & - & 3.7 & 2.8 & 20.4 & 23.1 & 19.4 & 27.8 & 2.8 \\
\hline 6 May & 10 & 0.6 & - & - & 50.0 & 30.0 & 20.0 & - & - & - & - & - \\
\hline 2 Jun & 135 & 6.9 & 0.7 & 67.4 & 25.2 & 5.9 & 0.7 & - & nd & nd & nd & nd \\
\hline 30 Jun & 1917 & 78.3 & 11.2 & 47.1 & 26.3 & 13.4 & 1.6 & 0.4 & - & 0.2 & - & - \\
\hline $31 \mathrm{Jul}$ & 1737 & 139.6 & 17.0 & 79.5 & 3.0 & 0.3 & - & - & - & 0.1 & - & - \\
\hline 26 Aug & 276 & 13.9 & 18.1 & 45.3 & 27.2 & 4.7 & 0.7 & 0.7 & 0.7 & 0.4 & 1.4 & 0.7 \\
\hline 28 Sep & 106 & 7.9 & 31.1 & 58.5 & 5.7 & 0.9 & 0.9 & - & 0.9 & 0.9 & 0.9 & - \\
\hline $26 \mathrm{Oct}$ & 256 & 5.8 & 0.4 & 11.7 & 10.9 & 11.7 & 17.6 & 16.8 & 16.0 & 10.2 & 2.7 & 2.0 \\
\hline $24 \mathrm{Nov}$ & 2345 & 167.3 & - & 8.5 & 35.1 & 50.5 & 4.6 & 0.8 & 0.3 & 0.1 & - & - \\
\hline $9 \mathrm{Dec}$ & 4255 & 206.2 & - & 1.1 & 25.9 & 44.7 & 16.6 & 7.1 & 2.0 & 1.6 & 0.7 & 0.2 \\
\hline 22 Jan 1993 & 246 & 8.8 & - & - & 2.0 & 7.3 & 14.6 & 23.6 & 26.4 & 21.5 & 3.3 & 1.2 \\
\hline \multicolumn{13}{|l|}{ Juveniles } \\
\hline 3 Mar 1992 & 23 & 1.0 & - & - & - & 13.0 & 13.0 & 34.8 & 13.0 & 13.0 & 13.0 & - \\
\hline $4 \mathrm{Apr}$ & 2 & 0.2 & - & - & - & - & - & - & 50.0 & - & - & 50.0 \\
\hline 6 May & 1 & 0.2 & - & 100.0 & - & - & - & - & - & - & - & - \\
\hline 2 Jun & 1751 & 139.2 & 0.9 & 79.5 & 15.9 & 3.1 & 0.6 & - & nd & nd & nd & nd \\
\hline 30 Jun & 3569 & 290.8 & 23.4 & 74.4 & 2.0 & 0.2 & - & - & - & - & - & - \\
\hline $31 \mathrm{Jul}$ & 1350 & 108.0 & 34.4 & 61.6 & 3.7 & 0.3 & - & - & - & - & - & - \\
\hline $26 \mathrm{Aug}$ & 31 & 1.7 & 35.5 & 45.2 & 16.1 & 3.2 & - & - & - & - & - & - \\
\hline 28 Sep & 292 & 22.6 & 19.9 & 72.9 & 6.5 & 0.3 & 0.3 & - & - & - & - & - \\
\hline 26 Oct & 202 & 7.3 & - & 24.8 & 24.3 & 15.8 & 6.9 & 8.4 & 8.4 & 5.4 & 3.0 & 3.0 \\
\hline 24 Nov & 5033 & 353.0 & - & 6.2 & 39.7 & 44.5 & 8.6 & 0.7 & 0.1 & 0.1 & - & - \\
\hline $9 \mathrm{Dec}$ & 1245 & 65.5 & - & 0.6 & 30.2 & 46.3 & 18.2 & 2.3 & 1.5 & 0.6 & 0.1 & 0.1 \\
\hline 22 Jan 1993 & 8 & 0.3 & - & - & - & 12.5 & 37.5 & 12.5 & 37.5 & - & - & - \\
\hline
\end{tabular}


Immature mysids appeared to show wider seasonal movement than adults (Table 5). In March and April, no immature mysids were taken in the $0-30 \mathrm{~m}$ zone, but occurred seaward of $30 \mathrm{~m}$ from the shoreline. In summer they moved shoreward and peaks of occurrence from early June to September were in the $10-20 \mathrm{~m}$ zone with ca $60 \%$ of the total catch taken there. From October through December, their range shifted and expanded seaward, and in January immature mysids showed a pattern similar to that observed in March-April.

Juveniles were distributed closer to the shoreline than adults and immature mysids (Table 5). From January to April, they were distributed in the offshore zone and no juveniles occurred in the $0-30 \mathrm{~m}$ zone. However from May to September they gathered in the $0-30 \mathrm{~m}$ zone and were rare in the $30-100 \mathrm{~m}$ zone. Mean percentages of occurrence for the $0-10,10-20$ and $20-30$ m zones during this period were $19.0,72.3$ and $7.2 \%$ respectively. From October their distribution shifted and expanded seaward as observed in adults and immature mysids.

\section{Microdistribution near the shoreline}

Archaeomysis grebnitzkii was not abundant in the microdistribution samples taken on 10 June 1993, and mature mysids were completely absent. Most juveniles and immature mysids were distributed slightly seawards of the step and no individuals were taken above the step (Fig. 3). A. grebnitzkii was distributed abundantly at Stns 11 to 13 . Its distributional range partly overlapped with that of $A$. kokuboi in the outer planar facies, but the 2 species did not co-occur elsewhere.

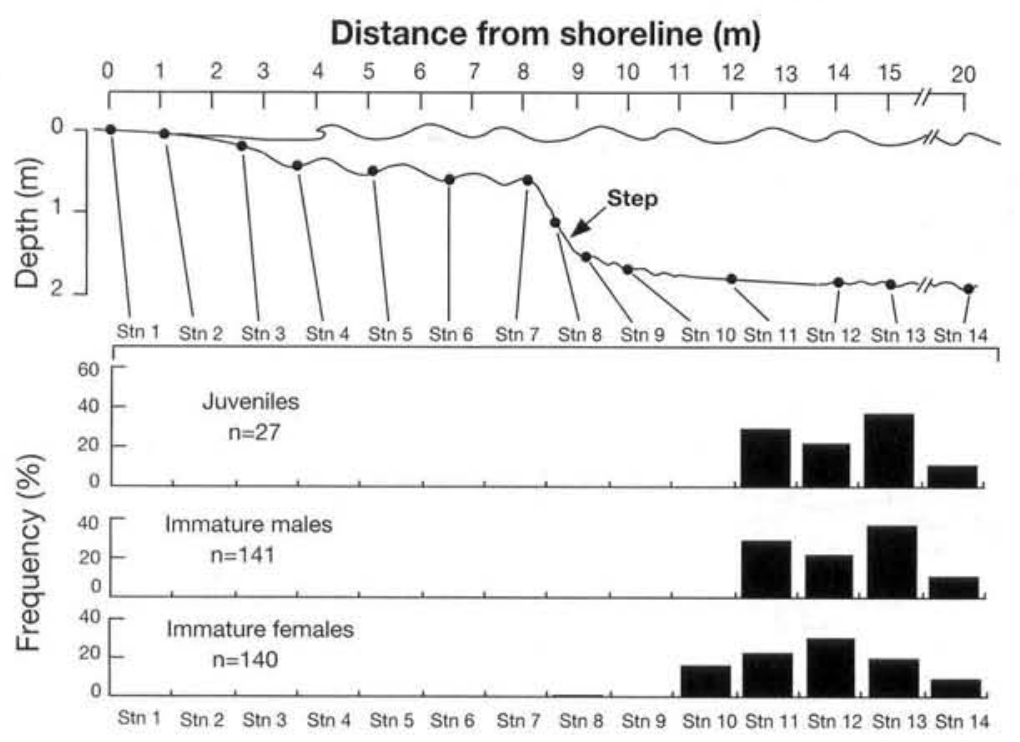

Fig. 3. Archaeomysis grebnitzkii. Microdistribution in the nearshore area, 10 June 1993 on Koshirahama Beach

\section{Seasonal changes in abundance}

Average densities of Archaeomysis grebnitzkii varied from 6.0 in May to 521.5 ind. $\mathrm{m}^{-2}$ in November (Table 4). In spring, density fluctuated at a low level around 6.0 to 10.2 ind. $\mathrm{m}^{-2}$, since a small number of individuals were distributed over a wide range. In June to July, their distributional range shifted shoreward and densities increased drastically to between 150.9 and 293.7 ind. $\mathrm{m}^{-2}$ mainly due to recruitment by juveniles. From August to October, densities once again decreased to between 13.6 and 26.4 ind. $\mathrm{m}^{-2}$, but from November to December, increased again to between 272.7 and 521.5 ind. $\mathrm{m}^{-2}$. In January density fell to 9.3 ind. $\mathrm{m}^{-2}$ which was similar to that of the spring.

\section{Distribution pattern of Iiella ohshimai}

Iiella ohshimai occurred in the study site from May to November and was especially abundant from late June to September (Table 6). Its total abundance was extremely low compared with that of the 2 Archaeomysis species. More than $99 \%$ of the total population was comprised of juveniles and immature mysids. Only 6 mature individuals were collected: 2 females with an empty brood pouch, 3 females with eyed larva and 1 male. Around May, the mysids seemed to move into the study site from a deeper area. From September to November they migrated to deeper water, leaving the study site during December through April. Although adults were infrequently encountered at this study site, a few mature individuals, including eggcarrying females, were captured at a depth of 4 to $5 \mathrm{~m}$ out of the study site from late spring to early summer, suggesting the possibility of aggregation in a shallower zone.

\section{DISCUSSION}

The distribution of Archaeomysis kokuboi was restricted to the swash zone and the area just beyond the step. This agrees with the fragmentary knowledge on the distribution of this species (Matsudaira et al. 1952, Kamihira 1979). This type of distribution has been reported in other sandy beach mysids such as Gastrosaccus sanctus (Fishelson \& Loya 1968, Moran 1972), G. simulans (Nath \& Pillai 1973), G. psammodytes (Wooldridge 1981, 1983) and $A$. vulgaris (Jo \& Hanamura 1993). 
Table 6. Iiella ohshimai. Monthly abundances (\% of total catch) in each sampling zone along a $100 \mathrm{~m}$ transect line at Koshirahama Beach. Values in parentheses are for mature individuals. Bold type indicates values $>10 \%,+:<0.1 \% ;-;$ no mysids collected; nd: no data

\begin{tabular}{|c|c|c|c|c|c|c|c|c|c|c|c|c|}
\hline \multirow[t]{2}{*}{ Date } & \multirow{2}{*}{$\begin{array}{l}\text { Total } \\
\text { catch }\end{array}$} & \multirow{2}{*}{$\begin{array}{l}\text { Average den- } \\
\text { sity (ind. } \mathrm{m}^{-2} \text { ) }\end{array}$} & \multicolumn{10}{|c|}{ Distance from shoreline $(\mathrm{m})$} \\
\hline & & & $0-10$ & $10-20$ & $20-30$ & $30-40$ & $40-50$ & $50-60$ & $60-70$ & $70-80$ & $80-90$ & $90-100$ \\
\hline 3 Mar 1992 & 0 & - & - & - & - & - & - & - & - & - & - & - \\
\hline $4 \mathrm{Apr}$ & 0 & - & - & - & - & - & - & - & - & - & - & - \\
\hline 6 May & 6 & 0.3 & - & - & - & - & - & - & - & 33.3 & $50.0(16.7)$ & 16.7 \\
\hline 2 Jun & 0 & - & - & - & - & - & - & - & nd & nd & nd & nd \\
\hline 30 Jun & 412 & 9.1 & - & 7.8 & 16.5 & 8.5 & 12.1 & 8.7 & 12.4 & 11.4 & $9.0 \quad 1$ & $13.6(0.2)$ \\
\hline $31 \mathrm{Jul}$ & 64 & 1.6 & - & - & 15.6 & 10.9 & 17.2 & 7.8 & 10.9 & 10.9 & 21.9 & 4.7 \\
\hline 26 Aug & 180 & 11.0 & - & 9.4 & 43.9 & 29.4 & $4.4(0.6)$ & $2.8(0.6)$ & 1.1 & 1.1 & 3.3 & 4.4 \\
\hline 28 Sep & 72 & 1.9 & - & 4.2 & 6.9 & 11.1 & 18.1 & 4.2 & 5.6 & 20.8 & 11.1 & 18.1 \\
\hline $26 \mathrm{Oct}$ & 9 & 0.5 & - & - & - & - & - & 11.1 & - & - & 22.2 & - \\
\hline $24 \mathrm{Nov}$ & 2 & 0.2 & - & - & - & - & - & - & 50.0 & 50.0 & - & - \\
\hline $9 \mathrm{Dec}$ & 0 & - & - & - & - & - & - & - & - & - & - & - \\
\hline 22 Jan 1993 & 0 & - & - & - & - & - & - & - & - & - & - & - \\
\hline
\end{tabular}

Clear intraspecific zonation was evident in Archaeomysis kokuboi at Koshirahama Beach (Fig. 4a). Juveniles were found below the step, while mature mysids occurred close to the shoreline. Immature mysids of both sexes occurred in the intermediate area between the shoreline and the area just beyond the step. Most

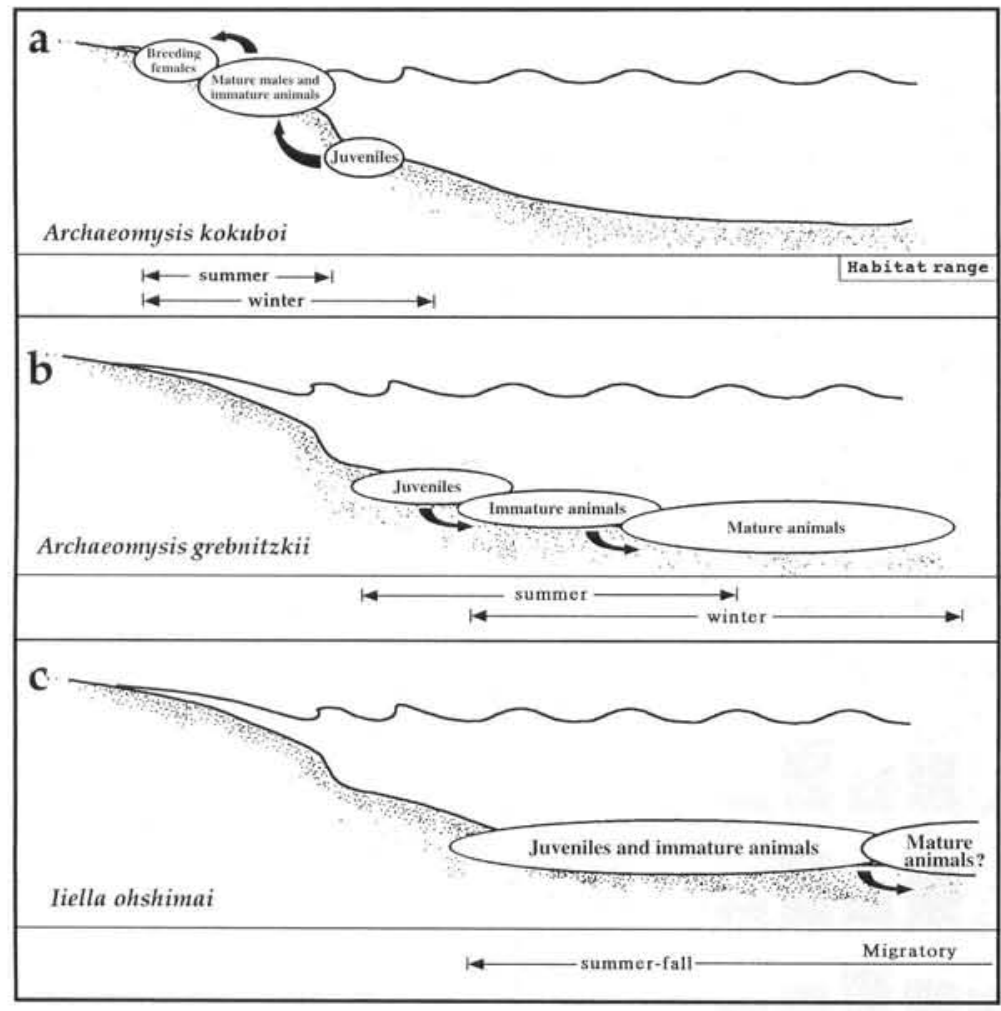

Fig. 4. Archaeomysis kokuboi, Archaeomysis grebnitzkii and Iiella ohshimai. Schematic diagram for inter- and intraspecific distributional patterns, Koshirahama Beach brooding females occurred in the narrow zone between 2 and $3 \mathrm{~m}$ from the shoreline. Shoreward movement such as this in brooding females has been reported in Gastrosaccus psammodytes, which inhabits sandy beaches in South Africa (Wooldridge 1981), though the beach type is different than that in the present study. Moreover, brooding females of $G$. simulans are known to occur predominantly during the monsoon season on sandy beaches in India (Nath \& Pillai 1973). The environment around the top of the swash zone is relatively calm compared to that of the slightly seaward zone, because the momentum of the waves is slackened by friction against the beach face. Shoreward movement of brooding females may be advantageous for the mysids as conserved energy may be directed into egg production rather than swimming activity and the mysids may avoid predation (Wooldridge 1981). A calmer environment may also lower the loss of embryos from the female's brood pouch (Wooldridge 1981). The shoreward movement of $A$. kokuboi brooding females is thought to be a good adaptation to increase their recruitment as reported for G. psammodytes. Most juveniles were distributed over and beyond the step where the bottom water is rather stagnant and various types of organic matter and debris accumulate. It is thought to be advantageous for small mysids to stay in this calm zone around the step, because of their low swimming ability and expected high availability of food. 
Archaeomysis grebnitzkii occurred in more offshore area than A. kokuboi throughout the year. From winter to spring, A. grebnitzkii was found in the area more than $40 \mathrm{~m}$ from the shoreline but during summer to fall it moved shoreward. This seasonal migration pattern may be common in A. grebnitzkii on Japanese sandy shores, since similar seasonal distribution patterns have been reported in the Japan Sea (Kajikawa 1978, Nishida et al. 1978, 1982, Hirota et al. 1988). Juveniles of A. grebnitzkii tended to occur closer to the shoreline than adults during summer, while mature mysids were distributed in more offshore areas undertaking seaward migration with growth (Fig. 4b).

Corresponding to the movement of the Archaeomysis grebnitzkii population to the shallower zone (within $30 \mathrm{~m}$ of the shoreline), Iiella ohshimai also migrated into the $20-100 \mathrm{~m}$ zone from deeper water during summer and fall. (Fig. 4c). The synchronized movement of these species has also been reported in the Japan Sea (Nishida et al. 1982) and thought a good adaptation for food resource or habitat partitioning. Almost all individuals of this species were juveniles or immature mysids, suggesting that adults of this species may inhabit deeper water. This distribution pattern also implies ontogenetic migration of $I$. ohshimai.

Juveniles of Archaeomysis grebnitzkii and Iiella ohshimai commonly occurred in more productive shallow zones than adults, especially during summer-fall. The shallower part of the sandy beach tends to accumulate various organic matter. Calmer sea conditions during summer may promote this accumulation and allow shoreward migration of the mysids. In addition, the shallow environment may be subject to less predation and its higher temperature may promote growth and maturation. Shallower areas may provide a suitable environment for the growth of smaller mysids.

At Koshirahama Beach, the 3 species of sandburrowing mysids show vertical zonation. This study has clearly revealed that the distributional ranges of Archaeomysis kokuboi and A. grebnitzkii are separated, though there was a narrow overlapping area at the outer planar facies which forms the boundary separating the 2 species. This habitat segregation is maintained throughout the year. It is known that structural facies readily shift both shoreward and seaward under varying wave and tide conditions (Clifton et al. 1971). As the sea is calm during summer at Koshirahama Beach, the outer planar facies moves shoreward, while in winter beach structures extend and the outer planar facies moves seaward. This is probably the main factor affecting the seasonal shift of the boundaries of both species (Tables $2 \&$ 4). The major features of each structural facies can be characterized in terms of flow regime (Clifton et al. 1971). It is known that a boundary exists at the inner rough facies or outer planar facies where the direction of water current changes (Clifton et al. 1971), suggesting that the accumulation of detritus or food organisms will occur in this area. In this context, water movement in the habitats of A. kokuboi and A. grebnitzkii is quite different and habitat segregation of both species may be caused by differences in behavioral responses to these flow regimes near the bottom.

The distribution boundary of Archaeomysis grebnitzkii and Iiella ohshimai is not as clear as that of the 2 species of Archaeomysis. I. ohshimai occurs on sand or mud substrates at depths between 5 and $20 \mathrm{~m}$ in Otsuchi Bay (Horikoshi et al. 1979) and in the Japan Sea at $75 \mathrm{~m}$ (Nishida et al. 1982). Thus $I$. ohshimai has a deeper depth range than A. grebnitzkii. Mature mysids, including brooding females are often captured at 4 to $5 \mathrm{~m}$ depths during late spring to early summer. This suggests they form breeding aggregations during late spring to early summer and probably release juveniles, thus the small mysids collected in shallower water.

Distribution patterns of the sand-burrowing mysids depicted here may be explained by the abundance, quality and availability of food that is determined by nearshore circulation patterns, and also by the feeding habits and diel rhythms of each species or developmental stage (Clutter 1967, Webb et al. 1988, Wooldridge 1989). To elucidate the distribution patterns of these sand-burrowing mysids, it is necessary to investigate the feeding behaviour of each species and the distribution of their food in the field.

Acknowledgements. We are most grateful to Captain K. Morita and Messrs T. Kawamura and K. Hirano of Otsuchi Marine Research Center, ORI, for their help with the field sampling. Mr T. P. Hirose and other staff of the Plankton Laboratory of ORI helped with the field work and contributed to fruitful discussions during the course of this study. We thank Drs Y. Hanamura and J. Mauchline and Mr D. Lindsay for critically reading and correcting the manuscript.

\section{LITERATURE CITED}

Clifton, H. E., Hunter, R. E., Phillips, R. L. (1971). Depositional structures and process in the non-barred high-energy nearshore. J. sedim. Petrol. 41: 651-670

Clutter, R. I. (1967). Zonation of nearshore mysids. Ecology 48: 200-208

Cockcroft, A. C., Webb, P., Wooldridge, T. (1988). Nitrogen regeneration by two surf-zone mysids, Mesopodopsis slabberi and Gastrosaccus psammodytes. Mar. Biol. 99: 75-82

Fishelson, L., Loya, Y. (1968). Preliminary observations on a population of Gastrosaccus sanctus (van Beneden) (Mysidacea, Crustacea) on a Mediterranean sand beach. Crustaceana 15: 149-152 
Hanamura, Y. (1992). A revision of littoral mysids of the genus Archaeomysis (Crustacea: Mysidacea) in the North Pacific Ocean. Ph.D. thesis, Hokkaido Univ.

Hirota, Y. (1992) . Vertical distribution of mysids and carrying capacity of ground fishes off Igarashi-Hama, Niigata. Contrib. Fish. Res. Japan Sea Block 23: 21-36 (in Japanese)

Hirota, Y., Noguchi, M., Koshiishi, Y. (1988). Assessment of carrying capacity of ground fishes based on the ecology of their food organisms. Marine Ranching Program Progress Report of Flounder Production 3: 203-215 (in Japanese)

Horikoshi, M., Tsuchida, E., Imajima, M., Takeda, M., Gamo, S., Ohta, S. (1979). Benthic invertebrates recorded from Otsuchi Bay and the adjustent Sanriku Coast - primary catalogue of fauna. Otsuchi mar. Res. Cent. Rep. 5: 37-85 (in Japanese)

Ii, N. (1964). Mysidae, Fauna Japonica. Biogeographical Society of Japan, Tokyo

Ito, T. (1985). Organisms in sand interstices. Kaimei Sha, Tokyo (in Japanese)

Jo, S.-G., Hanamura, Y. (1993). Redescription of mysid Archaeomysis vulgaris (Nakazawa 1910) Comb. Nov. (Crustacea: Mysidacea: Gastrosaccinae). Korean J. syst. Zool. 9: 103-113

Kajikawa, A. (1978). Note on mysids found in the waters off the sand hill of Tottori, with special reference to ecology of Acanthomysis nakazatoi. Bull, Tottori Pref. Fish. Exp. Stn 19: 53-70 (in Japanese)

Kamihira, Y. (1979). Ecological studies of macrofauna on a sandy beach of Hakodate, Japan II. On the distribution of peracarids and the factors influencing their distribution. Bull. Fac. Fish. Hokkaido Univ. 30: 133-143 (in Japanese with English abstract)

Matsudaira, C., Kariya, T., Tsuda, T. (1952). The study on the mysid Gastrosaccus vulgaris Nakazawa. Tohoku J. agric. Res. 3: 155-174

Mauchline, J. (1980). The biology of mysids and euphausiids. In: Blaxter, J. H. S., Russel, F., Young, M. (eds.) Advances in marine biology. Academic Press, London

Mauchline, J., Murano, M. (1977). World list of Mysidacea, Crustacea. J. Tokyo Univ. Fish. 64:39-88

This article was submitted to the editor
McLachlan, A., Wooldridge, T., Schramm, M., Kuhn, M. (1980). Seasonal abundance, biomass and feeding of shorebirds on sandy beaches in the eastern Cape, South Africa. Ostrich 51: 44-52

Moran, S. (1972). Ecology of distribution of the sand-dwelling mysid Gastrosaccus sanctus (van Beneden, 1861) along the Mediterranean sandy shore of Israel. Crustaceana (Suppl.) 3: 357-361

Moran, S., Fishelson, L. (1971). Predation of sand-dwelling mysid crustacean Gastrosaccus sanctus by plover birds (Charadriidae). Mar. Biol. 9: 63-64

MSA (Maritime Safety Agency) (1992). Tide tables, Vol. 1, Japan and its vicinities. MSA, Tokyo

Nath, C. N., Pillai, N. K. (1973). The alimentary system of the littoral mysid Gastrosaccus simulans (Van Beneden). J. mar. biol. Ass. India 15: 577-586

Nishida, T., Nozawa, M., Amio, M. (1978). Note on mysids found in the waters off the sand hill of Tottori, I. Bull. Tottori Pref. Fish. Exp. Stn 19: 1-52 (in Japanese)

Nishida, T., Nozawa, M., Amio, M. (1982). Note on mysids found in the waters off the sand hill of Tottori, II. Bull. Tottori Pref. Fish. Exp. Stn 24: 1-12 (in Japanese)

Webb, P., Perissinotto, R., Wooldridge, T. H. (1988). Diet and feeding of Gastrosaccus psammodytes (Crustacea, Mysidacea) with special reference to the surf diatom Anaulus birostratus. Mar. Ecol. Prog. Ser. 45: 255-261

Wooldridge, T. (1981). Zonation and distribution of the beach mysid, Gastrosaccus psammodytes (Crustacea: Mysidacea). J. Zool., Lond. 193: 183-189

Wooldridge, T. H. (1983). Ecology of beach and surf-zone mysid shrimps in the Eastern Cape, South Africa. In: McLachlan, A., Erasmus, T. (eds.) Sandy beaches as ecosystem. Junk Publishers, Hague, p. 449-460

Wooldridge, T. H. (1989). The spatial and temporal distribution of mysid shrimps and phytoplankton accumulations in high energy surf zone. Vie milieu 39: 127-133

Yamanaka, Y., Kosaka, K., Tsukawaki, S., Fujioka, K. (1990). Erosional, transporational and depositional processes of clastic sediments: Otsuchi bay as a natural laboratory, Part II. Otsuchi mar. Res. Cent. Rep. 16: 27-42 (in Japanese)

Manuscript first received: July 18, 1994

Revised version accepted: October 4, 1994 